\title{
THE EFFECTS OF 2,3-DIMERCAPTO-PROPANOL (BAL) ON GOLD REACTIONS
}

\author{
BY \\ GUNNAR EDSTRÖM \\ From the Arthritis Clinic and Department of University Hospital, \\ Lund, Sweden
}

During gold therapy of chronic arthritis two forms of undesired reaction may appear. One of these is a so-called " focal reaction ", i.e. a transitory exacerbation of some symptom or syndrome, such as increased capsular swelling, perioedema, tenderness on movements of one or more joints, mild elevation of body temperature, and rather pronounced iritic or conjunctival irritation. Reactions of this type are not rare, especially when higher doses of gold are employed, but as a rule they are not very troublesome and are relatively easy to control by a reduced or slower administration of the gold salts.

The other reaction, which is of a more malignant nature and not infrequently difficult to overcome, is the " hypersensitiveness complex reaction" manifesting itself in various ways, most frequently as a more or less severe dermatitis, sometimes as exfoliative dermatitis, sometimes as granulocytopenia or thrombocytopenia, sometimes as stomatitis or enterocolitis, sometimes as a more or less pronounced renal irritation.

In certain reactions, such as conjunctivitis or encephalitic irritation, it may be difficult to decide its exact nature, but the further clinical course usually clears up the problem.

That reactions of the second type are not toxic but due to hypersensitiveness seems evident, inter alia, from the fact that they appear to be unrelated to the concentration of gold in the plasma and its excretion from the body (Edström, 1948b). Moreover, the hypersensitiveness usually arises during the treatment, at its end, or several months later, and seldom produces an immediate eruption at the first injection. It is therefore difficult to prevent its occurrence. The goldtesting method experimentally worked out by Svanberg (an account of which he gave in 1949 at a meeting of the Swedish Association for Internal Medicine), appears to be more promising than earlier attempts, because it enables continuous control to be exercised during the treatment. In practice, however, continuous supervision of this kind would be difficult. It seems, therefore, that in the future we should reckon the appearance of such hypersensitiveness as a real crux in gold therapy.

Only one of these reactions seems exceptional in this respect. Since continuous administration of extra vitamin $\mathrm{C}$ to all patients was introduced at the Lund 
Arthritis Clinic during the second half of 1937 we have not had a single case of thrombocytopenia or any threat of such. The same observation has been made by Secher (1946).

No effective method of treating these hypersensitive reactions has hitherto been found. In BAL (2,3-dimercapto-propanol or British Anti-Lewisite) we seem now, however, to have obtained an effective remedy.

During the last two years reports have been published, especially in Great Britain and the U.S.A., of the effect of BAL on various hypersensitive and toxic reactions to a number of salts and compounds belonging to the As- $\mathrm{Sb}-\mathrm{Bi}$ series, or other heavy metals. It has been found to be of great clinical and therapeutic value in As reactions (Cohen and others, 1947; Carleton and others, 1948; Eagle, 1946), in Hg reactions (Longcope and Luetscher, 1946; Kanee and Stoffman, 1949), and in Au reactions (Burnett, 1947; Cohen and others, 1947; Davison, 1947; Macleod, 1948; Margolis and Caplan, 1947; Ragan and Boots, 1947; Simpson, 1948; Slot and McDonald, 1947; Sulzberger and others, 1946).

From the department in Lund a report has already been issued of the auric forms of dermatitis first treated with BAL (Edström, 1948a). Our experience has become wider during the past two years and this report now needs supplementing.

Since 1948 eleven cases of gold reaction have been treated with BAL at the Lund Arthritis Department. Data concerning ten of these, which had not previously been given BAL, are submitted in the following Table.

TABLE

RESPONSE OF GOLD REACTIONS TO TREATMENT WITH BAL

\begin{tabular}{|c|c|c|c|c|c|c|c|c|c|}
\hline \multirow{2}{*}{$\begin{array}{l}\text { Case } \\
\text { No. }\end{array}$} & \multirow{2}{*}{$\underset{\text { (years) }}{\text { Age }}$} & \multirow{2}{*}{$\begin{array}{l}\text { Duratio } \\
\text { morbis }\end{array}$} & \multirow{2}{*}{$\begin{array}{l}\text { Sedimen- } \\
\text { tation rate } \\
\text { at the } \\
\text { gold- } \\
\text { reactions } \\
\text { (per hour) }\end{array}$} & \multirow{2}{*}{$\begin{array}{c}\text { Total } \\
\text { gold- } \\
\text { prep. } \\
\text { (g.) }\end{array}$} & \multicolumn{2}{|c|}{$\begin{array}{l}\text { Interval between last } \\
\text { gold injection and }\end{array}$} & \multicolumn{2}{|c|}{ Effect of BAL on } & \multirow{2}{*}{$\begin{array}{l}\text { Gold } \\
\text { reaction }\end{array}$} \\
\hline & & & & & $\begin{array}{l}\text { onset of } \\
\text { rash } \\
\text { (days) }\end{array}$ & $\begin{array}{l}\text { first BAL- } \\
\text { injection } \\
\text { (days) }\end{array}$ & rash & pruritus & \\
\hline 1 & 837 & 6 months & 41 & $0.35 \mathrm{M}$ & 3 & 3 & good & good & dermatitis \\
\hline 2 & đo 52 & 5 years & 13 & $0 \cdot 25 \mathrm{M}$ & 4 & 4 & good & good & dermatitis + \\
\hline 3 & † 25 & 18 months & 8 & $0.50 \mathrm{M}$ & 60 & 150 & good & good & $\begin{array}{l}\text { nephritis } \\
\text { dermatitis }\end{array}$ \\
\hline 4 & $q 35$ & 2 months & 13 & $0 \cdot 30 \mathrm{M}$ & 7 & 50 & good & good & dermatitis \\
\hline 5 & 41 & 18 months & 44 & $1 \cdot 20 \mathrm{~A}$ & 4 & 4 & good & good & dermatitis + \\
\hline 6 & $\uparrow 53$ & 5 months & 20 & $0.45 \mathrm{M}$ & 6 & 11 & good & good & $\begin{array}{l}\text { conjunctivitis } \\
\text { dermatitis }\end{array}$ \\
\hline 7 & $q 40$ & 41 months & 28 & $7 \cdot 20 \mathrm{~A}$ & 1 & 6 & none & little & dermatitis \\
\hline 8 & q50 & 18 months & 20 & $6.0 \mathrm{~A}$ & 17 & 22 & good & good & dermatitis + \\
\hline 9 & o 48 & 5 months & 13 & $7 \cdot 40 \mathrm{~A}$ & 2 & 11 & good & good & $\begin{array}{l}\text { conjunctivitis } \\
\text { dermatitis }+\end{array}$ \\
\hline 10 & ơ 43 & 10 years & 36 & $0.95 \mathrm{M}$ & 14 & 36 & good & good & $\begin{array}{c}\text { dermatitis } \\
\text { conjunctivitis }\end{array}$ \\
\hline
\end{tabular}

Only in one of these (No. 7, a fresh case) was there no effect from the BAL medicament. In this case, treatment of the dermatitis was continued by the older method with Ca- and Na-thiosulphate injections, Burow's compresses, ointment 
and potassium permanganate baths, and recovery followed in about six weeks. Nevertheless, in this case also a slight diminution of pruritus resulted from the BAL injections.

In the other nine cases the introduction of BAL treatment gave prompt results. Pruritus was the first symptom to diminish. After the BAL injections the itching began to subside, in one case it abated after the second injection, and in all within 48 hours; after three to four days it had vanished. The exanthema was little affected at first, but after three to five days a distinct abatement was observed, the redness and swelling in the skin lessened and after ten to fourteen days the exanthemata had practically disappeared. The lesions of the mucous membranes, aphthae, stomatitis, enteritis, etc., began to disappear at the same time. Microscopic haematuria often appeared concurrently with the dermatitis (in this series in four cases); this did not disappear during the first few days of the BAL medication and in one case it even increased. Whether this can be associated with the BAL cannot be decided, but during the second week of treatment it disappeared entirely in all cases. Conjunctivitis (present in four cases-in one with a severe marginal ulceration) always underwent improvement parallel with the dermatitis. Liver disorder was observed in none of these cases (Takata and Bilirubin/serum were normal). Granulocytopenia or thrombocytopenia were not observed. None of these nine cases had any symptom left of their gold reaction a fortnight after the introduction of BAL medication.

An interesting observation was that a beneficial effect from BAL medication was also obtained in the three cases in which the gold dermatitis had lasted a longish time. In one it had persisted for three months, defying all therapy, and was in a severe exfoliative phase when the BAL medication was started, but vanished completely within a fortnight of the introduction of BAL. In another case the patient entered with an exfoliative dermatitis that had lasted six weeks. Case No. 7, in which no effect was observed, was a fresh one, but had had very large doses of gold.

These gold reactions are always very variable in their course, and it is difficult at first to judge how a reaction will continue to develop, but a pronounced dermatitis of this nature seldom subsides in less than six weeks without BAL. It may sometimes last for many months, even for two years. The most troublesome feature for the patients is the intense itching, and BAL has its most pronounced effect on this symptom. Even in the one (No. 7) in which the dermatitis was not objectively affected by the BAL treatment an unmistakable mitigation of the pruritus was obtained after a couple of days' treatment. In the remaining nine cases this alleviation appeared during the first 48 hours.

The eleventh case is particularly interesting. A 72-year-old woman with severe rheumatoid arthritis had been treated at another hospital with Myoral (calcium aurothiogluconate), total amount $2.15 \mathrm{~g}$. or $1.38 \mathrm{~g}$. Au. She became almost free from her arthritis symptoms, and stayed at a summer health resort in good general condition and with a normal sedimentation rate. About seven weeks after the last gold injection she began to be troubled with itching in her hair 
and on her neck. After a few days weeping exanthemata broke out on her hands, and rapidly spread over trunk and limbs. About six weeks after the appearance of the dermatitis she was re-admitted to the same hospital, where Au dermatitis was diagnosed. She was given in all 10 ampoules of BAL (i.e. about $3 \mathrm{mg} . / \mathrm{kg}$. bodyweight in each dose or ampoule) for a few days daily and then every other day, this treatment being without effect (the dose was too small, see below). About two months later she was admitted to the Lund Arthritis Clinic with a violent exfoliate dermatitis. BAL therapy was instituted in collaboration with the Lund Clinic of Dermatology. After the second BAL injection the patient reacted with a violent blazing up of the dermatitis, intense pruritus, and reddening and swelling of the skin, and not for about six weeks could the dermatitis be brought to subside with the method previously adopted.

From what appeared at a later test hypersensitiveness to BAL had arisen. BAL is an As preparation and is subject to the disadvantages of such preparations. This case shows that a hypersensitive reaction against BAL can arise. However, Sulzberger and others (1946) and Macleod (1948) have shown that it is possible to repeat BAL treatment without such a reaction.

In every case BAL was given in a dose of $2.5 \mathrm{mg}$. $/ \mathrm{kg}$. bodyweight every four hours during the first 24 hours and then twice daily for ten days. In two cases the course was continued for fourteen days; in one the injections were interrupted on the fifth day on account of local trouble at the site of injection; in one the injections were stopped on the seventh day as the patient was totally free from symptoms; in one the injections were stopped on the eighth day for the same reason, but had to be resumed three days later, upon the reappearance of the exanthema, and were then continued a further seven days; in one case with haematuria the dose was diminished to once daily after the fourth day.

To obtain good results it is important that BAL be given in sufficiently big doses and at short enough intervals, especially during the first 24 hours. According to the original directions for use of BAL that were employed here, it should be administered in a dose of $2.5 \mathrm{mg}$. $/ \mathrm{kg}$. bodyweight every four hours during the first 24 hours of treatment. This dose is based upon experiments on rats and voluntary human subjects, by Peters and other investigators in Oxford, according to which 80 per cent. of the injected BAL enters the circulation within one hour, and the maximum concentration in the blood from a single dose is attained within two hours. After four hours the concentration has fallen to less than half the maximum. A single dose of this size is entirely excreted within 6 to 24 hours according to the individual. To obtain any effect a high concentration must be maintained during at least the first 24 hours of treatment. The question is whether these doses and intervals are sufficient when the patients have had such high gold doses, as are given in some places in Europe. It is possible that in relation to the amount of gold in the body the doses were too small and the intervals between injections too long in case 7, where no effect resulted from BAL medication.

By their investigations Peters and others (1947), Spray (1947), and Thompson 
and Whittaker (1947) have shown it to be probable that it is not the increased excretion of Au brought about by BAL (Ragan and Boots, 1947-also seen in the Lund Arthritis Department) that is the essential effect, but the fact that BAL binds $\mathrm{Au}$ in the tissues into a non-toxic compound. Using BAL containing radioactive sulphur, Peters and others have thoroughly investigated the metabolism of BAL. Webb and van Heyningen (1947) and Barron and others (1947) have shown that BAL inhibits some of the enzymes in the body such as catalase and peroxidase. Of practical importance is the fact that BAL diminishes the effect of insulin.

Levy and Smyth (1947) and Gillmor and Freyberg (1947) have shown that BAL obviates exitus of rats given lethal doses of $\mathrm{Au}$, and greatly reduces the pathological effect of sub-lethal doses. The sooner BAL is administered after the gold injection the greater is its effect.

The undesirable side-effects that may arise from BAL have been especially studied by Gold (1948). Nausea, vomiting, salivation, increased flow of tears, paraesthesia, and headache may arise. Tachycardia and a mild increase in bloodpressure have occasionally been observed, and also mild muscle spasms. All these symptoms, however, are relatively mild and transient. Sulzberger and others (1946), and Modell and others (1946) have shown by tests on voluntary human subjects, that it is possible to give $5 \mathrm{mg}$. $/ \mathrm{kg}$. bodyweight without toxic effects, and that such toxic effects do not appear with less than $8 \mathrm{mg}$. $/ \mathrm{kg}$. bodyweight. Liver lesions contra-indicate BAL treatment.

The local troubles of the BAL injections are more deserving of attention. In almost all cases of this series local troubles arose during the first injections, such as local swelling, infiltration, perioedema, tenderness, and pains, but in no case did an abscess formation result, and the symptoms usually ceased after a few days. Sometimes they may be so troublesome as to necessitate an interruption of the injections - as in one of these cases. In none except the above-mentioned were undesirable side-effects obtained.

Judging from the literature, the number of cases of gold reaction treated with BAL is still less than one hundred. The results agree with those obtained here: the effect in general is good, with sporadic exceptions. Parallel experience has been gained in the treatment of $\mathrm{As}$ and $\mathrm{Hg}$ reactions with $\mathrm{BAL}$, when the observed side-effects were mostly less troublesome.

BAL therapy must be regarded as an essential advance in the treatment of hypersensitive reactions due to gold.

\section{Summary}

(1) Eleven cases of dermatitis and other reactions due to gold have been treated with intramuscular injections of BAL (2,3-dimercapto-propanol): in nine cases successfully, in one case without effect, in one case with hypersensitive reaction to BAL.

(2) In six cases the gold reactions were fresh, and BAL treatment was successful in five of them. In the other five cases the gold dermatitis and the other reactions 
were of longer standing, and the effect of the BAL treatment was good in four of them. The oldest case had had her gold dermatitis for three months, with exanthemata over the legs, trunk, and arms in an exfoliative stage. Within a few hours after the first BAL injection the pruritus began to recede; after three days the rash cleared up and it had disappeared entirely in ten days.

(3) The case with the hypersensitive reaction to BAL had also had her gold dermatitis for three months. Two months earlier she had received small doses of BAL at another hospital-too small to have any therapeutic effect. With repeated BAL treatment this hypersensitive reaction resulted.

(4) In four cases microscopic haematuria was observed. This haematuria in some of these cases was a little more pronounced during the early days of the BAL treatment, but then began to disappear.

(5) Pains and transient infiltrations at the place of injection were in most cases observed during the first day of injection, becoming less pronounced later. No headache, nausea, vomiting, salivation, paraesthesia, pains, or cramps in the muscles were observed as side effects of BAL.

(6) The treatment of gold reactions has taken a great step forward with BAL therapy, but caution is recommended in its use.

\section{REFERENCES}

Barron, E. S. G., Miller, Z. B., and Meyer, J. (1947). Biochem. J., 41, 78.

Burnett, J. A. (1947). Brit. med. J., 2, 670.

Carleton, A., Peters, R. A., and Thompson, R. H. S. (1948). Quart. J. Med., 17, 49.

Cohen, A., Goldman, J., and Dubbs, A. W. (1947). J. Amer. med. Ass., 133, 749.

Davison, R. A. (1947). Stanford med. Bull., 5, 37.

Eagle, H. (1946). J. vener. Dis. Inform., 27, 114.

Edström, G. (1948a). Nord. Med., 37, 30.

- (1948b). Acta med. scand., 131, 571.

Gillmor, C. S., and Freyberg, R. (1948). J. Lab. clin. Med., 33, 1024.

Gold, H. (1948). Amer. J. Med., 4, 1.

Kanee, B., and Stoffman, I. (1949). Canad. med. Ass. J., 60, 292.

Levey, S., and Smyth, C. J. (1947). J. Lab. clin. Med., 32, 1364.

Lockie, L. M., Norcross, B. M., and George, C. W. (1947). J. Amer. med. Ass., 133, 754.

Longcope, W. J., and Luetscher, J. A., Jr. (1946). J. clin. Invest., 25, 557.

Macleod, J. G. (1948). Annals of the Rheumatic Diseases, 7, 143.

Margolis, H. M., and Caplan, P. S. (1947). Ann. intern. Med., 27, 353.

Modell, W., Gold, H., and Cattell, M. (1946). J. clin. Invest., 25, 480.

Peters, R. A., Spray, G. H., Stocker, L. A., Collie, C. H., Grace, M. A., and Wheatley, G. A. (1947). Biochem. J., 41, 370.

Ragan, C., and Boots, R. H. (1947). J. Amer. med. Ass., 133, 752.

Secher, K. (1946). "The Treatment of Rheumatic Joint Diseases", Copenhagen.

Simpson, N. R. W. (1948). Brit. med. J., 1, 545.

Slot, G., and McDonald, A. D. (1947). Ibid., 2, 773.

Spray, G. H. (1947). Biochem. J., 41, 360, 366.

, Stocker, L. A., and Thompson, R. H. S. (1947). Ibid., 41, 362.

Sulzberger, M. B., Baer, R. L., and Kanof, A. (1946). J. clin. Invest., 25, 480.

Svanberg, T. (1950). Annals of the Rheumatic Diseases. (In the press.)

Thompson, R. H. S., and Whittaker, V. P. (1947). Biochem. J., 41, 342.

Webb, E. C., and Van Heyningen, R. (1947). Ibid., 41, 74.

Efiet du 2,3-dimercapto-propanol (BAL) sur les Réactions dues à l'Or RÉSuMÉ

(1) Onze cas de dermatite et d'autres réactions dues à l'or furent traités par des injections intramusculaires de BAL (2,3-dimercapto-propanol): neuf cas avec succes, un cas sans effet, et dans un cas il y eut une réaction d'hypersensibilité au BAL. 
(2) Le traitement au BAL réussit dans cinq cas sur six de réaction à l'or de date récente. Il fut aussi favorable dans quatre sur les autres cinq cas où la dermatite et les autres réactions à l'or étaient établies depuis plus longtemps. Le cas le plus ancien souffrait de sa dermatite due à l'or depuis trois mois, avec l'exanthème des jambes, du tronc, et des bras au stade de desquamation. Cinq heures après la première injection de BAL le prurit commença à céder; trois jours plus tard l'exanthème s'éclaircit pour disparaître entièrement au bout de dix jours.

(3) Le cas de réaction d'hypersensibilité au BAL avait aussi présenté sa dermatite à l'or depuis trois mois. Deux mois auparavant cette malade avait été traitée par de petites doses de BAL dans un autre hôpital-trop petites pour produire un effet thérapeutique. La réaction d'hypersensibilité apparut par suite d'un traitement répété au BAL.

(4) Dans quatre cas on observa une hématurie microscopique. Dans certains de ces cas l'hématurie fut un peu plus prononcée durant les premiers jours du traitement au BAL et disparut progressivement après.

(5) Des douleurs et des infiltrations passagères à l'endroit des injections furent observées dans la plupart des cas au premier jour du traitement; plus tard elles devinrent moins prononcées. On ne constata pas d'effets secondaires du BAL tels que céphalée, nausée, vomissements, sialorrhée, paresthésie, douleurs, ou crampes musculaires.

(6) Le traitement des réactions dues à l'or a accusé un grand progrès grâce au BAL, il est toutefois conseillé de s'en servir avec prudence.

\section{Efecto del 2,3-dimercapto-propanol (BAL) sobre la Reacciones debidas al Oro RESUMEN}

(1) Once casos de dermatitis y de otras reacciones debidas al oro fueron tratados por inyecciones intramusculares de BAL (2,3-dimercapto-propanol): con éxito, uno sin efecto, y en un caso hubo reacción de hipersensibilidad al BAL.

(2) Seis casos de reacciones al oro eran recientes y el tratamiento con BAL tuvo éxito en cinco de ellos. En los demás cinco casos la dermatitis y las otras reacciones debidas al oro habían existido desde algún tiempo y el efecto del tratamiento por BAL fué bueno en cuatro de ellos. El caso más antiguo había sufrido de su dermatitis debida al oro desde tres meses, con exantema de piernas, tronco, y brazos en el período de exfoliación. Cinco horas despuès de la primera inyección de BAL el prurito empezó a diminuir; tres días más tarde la erupción se aclareció para desaparecer enteramente dentro de diez días.

(3) El caso de reacción de hipersensibilidad al BAL había también presentado su dermatitis debida al oro desde tres meses. Dos meses antes esta enferma había recibido pequeñas dosis de BAL en otro hospital-demasiado pequeñas para producir efecto terapéutico. La reacción de hipersensibilidad resultó del tratamiento repetido por BAL.

(4) En cuatro casos hubo hematuria microscópica. En algunos de estos casos le hematuria fué algo pronunciada durante los primeros días del tratamiento por BAL, pero luego empezó a desaparecer.

(5) Dolores e infiltraciones transitorios en el sitio de las inyecciones fueron observados en la mayoría de los casos durante el primer día del tratamiento; luego se volvieron menos acentuados. No se vió efectos secundarios del BAL, tales como dolor de cabeza, náusea, vómitos, sialorea, parestesia, dolores, o calambres musculares.

(6) El tratamiento de las reacciones debidas al oro ha progresado mucho gracias al BAL, pero se aconseja prudencia en su empleo.

\section{CORRECTION}

Attention is drawn to the following error, which appeared in the Table to illustrate the article " Pituitary Gland Implantations in Rheumatoid Arthritis " by Gunnar Edström in the Annals of the Rheumatic Diseases, vol. 9, p. 22. The heading to the last two columns should read "Blood Sedimentation Rate per Hour, before Implantations and after Implantations ". 